\title{
Spatially explicit analysis of gastropod biodiversity in ancient Lake Ohrid
}

\author{
T. Hauffe ${ }^{1}$, C. Albrecht ${ }^{1}$, K. Schreiber ${ }^{1}$, K. Birkhofer ${ }^{1}$, S. Trajanovski ${ }^{2}$, and T. Wilke ${ }^{1}$ \\ ${ }^{1}$ Department of Animal Ecology and Systematics, Justus Liebig University, Giessen, Germany \\ ${ }^{2}$ Department of Zoobenthos, Hydrobiological Institute Ohrid, Ohrid, Macedonia
}

Received: 21 May 2010 - Published in Biogeosciences Discuss.: 1 July 2010

Revised: 7 January 2011 - Accepted: 13 January 2011 - Published: 26 January 2011

\begin{abstract}
The quality of spatial analyses of biodiversity is improved by (i) utilizing study areas with well defined physiogeographical boundaries, (ii) limiting the impact of widespread species, and (iii) using taxa with heterogeneous distributions. These conditions are typically met by ecosystems such as oceanic islands or ancient lakes and their biota. While research on ancient lakes has contributed significantly to our understanding of evolutionary processes, statistically sound studies of spatial variation of extant biodiversity have been hampered by the frequently vast size of ancient lakes, their limited accessibility, and the lack of scientific infrastructure. The European ancient Lake Ohrid provides a rare opportunity for such a reliable spatial study. The comprehensive horizontal and vertical sampling of a speciesrich taxon, the Gastropoda, presented here, revealed interesting patterns of biodiversity, which, in part, have not been shown before for other ancient lakes.

In a total of 284 samples from 224 different locations throughout the Ohrid Basin, 68 gastropod species, with 50 of them $(=73.5 \%)$ being endemic, could be reported. The spatial distribution of these species shows the following characteristics: (i) within Lake Ohrid, the most frequent species are endemic taxa with a wide depth range, (ii) widespread species (i.e. those occurring throughout the Balkans or beyond) are rare and mainly occur in the upper layer of the lake, (iii) while the total number of species decreases with water depth, the proportion of endemics increases, and (iv) the deeper layers of Lake Ohrid appear to have a higher spatial homogeneity of biodiversity. Moreover, gastropod communities of Lake Ohrid and its feeder springs are both distinct from each other and from the surrounding waters. The analysis also shows that community similarity of Lake
\end{abstract}

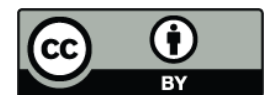

Correspondence to: T. Hauffe (torsten.hauffe@bio.uni-giessen.de)
Ohrid is mainly driven by niche processes (e.g. environmental factors), but also by neutral processes (e.g. dispersal limitation and evolutionary histories of species). For niche-based mechanisms it is shown that large scale effects such as type of water body or water depth are mainly responsible for the similarity of gastropod communities, whereas small scale effects like environmental gradients affect gastropod compositions only marginally. In fact, neutral processes appear to be more important than the small scale environmental factors, thus emphasizing the importance of dispersal capacities and evolutionary histories of species.

\section{Introduction}

Biodiversity, the variation among living organisms or ecosystems (UNEP, 1992), is a multi-factorial concept. Ecosystem diversity can be assessed by a combination of $\alpha$-diversity (i.e. species richness at one location), $\beta$-diversity (i.e. variation in species assemblages among locations), and $\gamma$-diversity (i.e. the total number of species of the ecosystem; Whittaker, 1972). Biodiversity is known to be heterogeneous in time (e.g., Gaston, 2000; Rohde and Muller, 2005; Weir, 2006) and space (e.g., Diniz-Filho and Bini, 2005; Buckley and Jetz, 2008). In general, spatial distribution of biodiversity is explained by two partly overlapping concepts. On the one hand, it is thought to be shaped both by large scale factors such as latitudinal gradient, altitude, water depth, and peninsula or bay effects, and by smaller scale factors such as habitat heterogeneity, barriers to dispersal, predation, competition or mutual stimulation (Gaston and Spicer, 2005). The second concept assumes that differences in community composition are caused by: (i) purely biological interactions, such as competition and mutualism, (ii) neutral processes like speciation, extinction or dispersal limitation of species,

Published by Copernicus Publications on behalf of the European Geosciences Union. 
or (iii) processes based on the species' niche, acting via environmental factors such as climate (Legendre et al., 2005).

Unfortunately, our knowledge of biodiversity patterns is strongly biased towards marine or terrestrial habitats (Gaston and Spicer, 2005), and to conspicuous taxa like vertebrates (e.g., Abell et al., 2008; Strayer, 2006). Thus, our level of understanding of patterns in freshwater invertebrate distribution remains limited, raising the need for comprehensive studies (Hof et al., 2008).

To enable a spatial analysis of freshwater biodiversity, some prerequisites should be fulfilled: (i) ideally the area studied should be well defined based on natural entities rather than geopolitical ones, (ii) the majority of the studied taxa should occur exclusively in the study area to reduce the impact of widespread species on biodiversity estimates and to avoid scaling problems (Albert et al., 2010), and (iii) the taxon of interest should be characterized by high biodiversity and in-homogenous distribution to diminish the correlation between local and regional diversity relationships (Gaston and Spicer, 2005).

The first prerequisite is typically met by ancient lakes, that is, water bodies that have continuously existed for at least hundred thousand years. They often show a high degree of biodiversity and have inspired numerous studies of both fossil (Williamson, 1981; Van Boxclaer et al., 2008; Harzhauser and Mandic, 2008) and extant lake biota (Wilson et al., 2004; Herder et al., 2006). Cohen (1994) emphasized that the species richness we see in ancient lakes today could be a temporary snapshot. Lake-level fluctuations and changes of basin morphology with considerable effects on lake biota, for example, are well documented for ancient lakes of the east African Rift Valley (e.g., Cohen et al., 2007; Scholz et al., 2007; Schultheiß et al., 2009, 2011), Lake Baikal (Kashiwaya et al., 2001), or the Caspian Sea (Reid and Orlova, 2002; Grigorovich et al., 2002). Comparable data about hydrological changes in the European ancient Lake Ohrid have been published only recently (Belmecheri et al., 2009; Lindhorst et al., 2010).

Lake Ohrid is a graben lake of bathtub shape with a maximum depth of $289 \mathrm{~m}$, a surface area of $358 \mathrm{~km}^{2}$ and a volume of $55 \mathrm{~km}^{3}$ (Matzinger, 2006b). Hence, it is one of the smallest ancient lakes of the world. Nevertheless, the Ohrid Basin has a complex geological and limnological structure. Different bedrock types, active tectonics (for details see Hoffmann et al., 2010), steep-sided mountain ranges, and water-discharge by lake-side and sublacustrine spring fields (Matzinger et al., 2006a) cause the characteristics of different habitats (Fig. 1). Some workers have suggested that these complex features are partly responsible for a high number of ecological niches and the outstanding degree of biodiversity (Radoman, 1985; Albrecht and Wilke, 2008). In the latter regard, Lake Ohrid differs from many other old Balkan lake systems (Albrecht et al., 2009; Marková et al., 2010; Trajanovski et al., 2010).

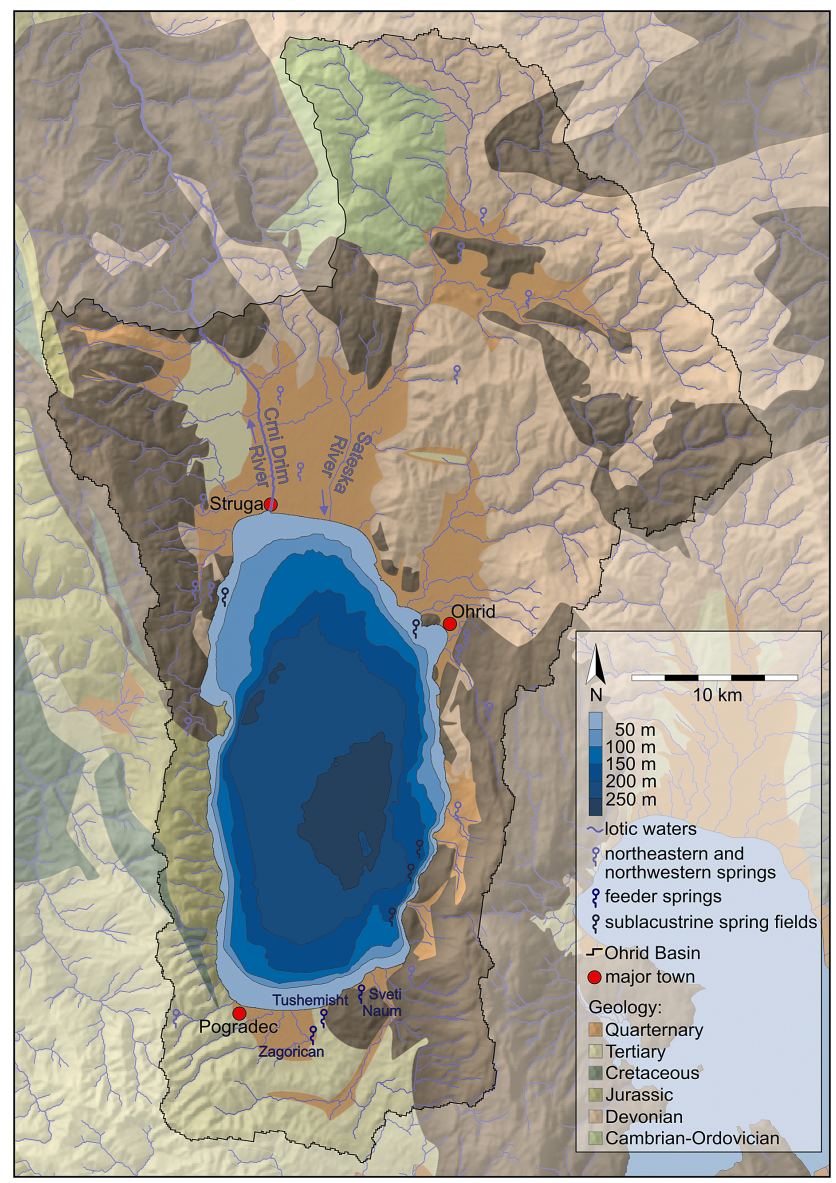

Fig. 1. Map of the Ohrid Basin showing major hydrological and geological features. Map adapted from Hoffman et al. (2010).

While Lake Ohrid, indeed, possesses a relatively isolated basin, thus fulfilling criterion (i) for spatial analysis of freshwater biodiversity, criteria (ii) and (iii), addressing taxonomic requirements, are met by representatives of its gastropod fauna. The vast majority of Lake Ohrid's gastropod species is morphologically relatively easy to distinguish and gastropods probably constitute the best studied invertebrate taxon in the lake (e.g., Poliński, 1929; Hubendick and Radoman, 1959; Radoman, 1985; Hauswald et al., 2008; Wilke et al., 2009). Recently, even the first fossil molluscs have been reported from the Last Interglacial period (Albrecht et al., 2010). Moreover, there is growing evidence for vertical and horizontal gradients and barriers within the Ohrid Basin (Albrecht et al., 2006, 2008; Wysocka et al., 2008; Trajanovski et al., 2010), possibly promoting parapatrical or even allopatrical speciation events (Albrecht and Wilke, 2008). Despite these interesting findings, a comprehensive picture of the spatial distribution of gastropod biodiversity within Lake Ohrid is still missing. However, this is not a problem typical for Lake Ohrid. In fact, we have no knowledge of any ancient lake in the world where a species-rich invertebrate 
taxon has been sampled in a manner allowing for statistically sound studies of the spatial distribution of biodiversity. Reasons include the often large size of ancient lakes, their, in part, limited accessibility (both physically and politically), and the lack of infrastructure for lake-wide biodiversity studies.

In this regard, Lake Ohrid constitutes a rare exception. Not only does the relatively small size of the lake allow for comprehensive sampling but the lake is also readily accessible, and infrastructure for lake-wide biodiversity studies can be regarded as excellent. Given this unique opportunity for a comprehensive horizontal and vertical sampling of a speciesrich taxon over a whole ancient lake basin, we are using information from 224 collecting points for gastropods from Lake Ohrid to:

i. provide a comprehensive assessment of Lake Ohrid's gastropod diversity,

ii. identify potential faunal subdivisions of the Ohrid Basin utilizing a multivariate framework,

iii. provide a spatially-explicit description of biodiversity patterns within the lake proper, and

iv. assess the differential contribution of neutral versus niche based processes.

\section{Material and methods}

\subsection{Zonation of the Ohrid Basin}

The basin of Lake Ohrid (Fig. 1) has a size of $1605 \mathrm{~km}^{2}$ (calculated based on SRTM-3 data from the year 2000) and consists of the lake itself with different depth layers as well as different zones in the surroundings, i.e. lotic waters, pools, and springs.

\subsubsection{Lake Ohrid}

The vertical subdivision of worldwide lakes is typically based on the degree of benthic photic production with the littoral being the zone of macrophytic vegetation and the profundal being the layer without photic production. In deep oligotrophic lakes such as Lake Ohrid, it is difficult to infer an exact zonation based on biotic factors. Thus, we here adopted a strictly hydrological approach based on lake-level fluctuations and the location of the summer thermocline.

\section{Surface Layer}

The Surface Layer is the upper vertical zone in Lake Ohrid down to approximately $5 \mathrm{~m}$ depth. It is affected by wave action (Stanković, 1960), intra-annual lake-level fluctuations (which today are regulated to only $1 \mathrm{~m}$; Popovska and Bonacci, 2007), and high seasonal temperature variations
(Stanković, 1960). The vegetation of the Surface Layer consists mostly of microalgae and extensive reed belts at the northern and southern shores (Watzin et al., 2002). Based on prevailing abiotic conditions, such as sublacustrine spring fields, substrate type and differences in geology (Hoffman et al., 2010), a horizontal zonation of the Surface Layer has been suggested (Albrecht and Wilke, 2008).

\section{Intermediate Layer}

The Intermediate Layer between $5-25 \mathrm{~m}$ water depth is summer-stratified by a relatively steep temperature decline and an increase of dissolved oxygen. It consists of a partly continuous belt of Chara algae (Lindhorst et al., 2010), which supposedly impedes the migration of benthic invertebrates (Albrecht et al., 2006; Sell et al., 2007; Wysocka et al., 2008; Trajanovski et al., 2010). The shell zone below the Chara-belt is characterized by wide Dreissena beds (e.g., Wilke et al., 2010) and sparse macrophytes (Stanković, 1960).

\section{Deep Layer}

The upper boundary of the Deep Layer is characterized by the end of the summer thermocline at $\sim 25 \mathrm{~m}$ (Watzin et al., 2002) and relatively high oxygen saturation (Stanković, 1960). As the first zone of definite fine-grained sediment deposition (Stanković, 1960), the substratum consists mainly of silt and mud (Vogel et al., 2010), and sporadic oxygendepletion influences organic matter preservation (Holtvoeth et al., 2010). Below the $50 \mathrm{~m}$ isobath, there is no benthic photic production (Stanković, 1960).

\subsection{Springs}

Springs represent an important hydrological system in the Ohrid Basin as they are responsible for a considerable part of its water balance. They can be found within the lake (i.e. sublacustrine spring fields) or along the margins. Many of them are located in the northwest and northeast of the lake, but the most powerful springs are the feeder spring complexes of Sv. Naum (Macedonia) and Tushemisht/Zagorican (Albania) in the south. They form spring lakes of up to $5 \mathrm{~m}$ depth (Kunz, 2006). Mainly supplied by neighbouring Lake Prespa, the feeder-springs are characterized by different water chemistry than the mainly precipitation-fed springs in the northeast and northwest (Matzinger et al., 2006a). Thus, we here distinguish between the southern feeder-springs and the northeastern/northwestern springs.

\subsubsection{Lotic waters and pools}

Many of the northeastern and northwestern springs give rise to creeks and small, often artificial pools. Due to the steepsided basin shape, the lotic waters are mainly short, shallow and often subject to seasonal desiccations. The two main 
lotic waters in the area are the effluent Crni Drim River and the affluent Sateska River (Fig. 1). The latter was artificially diverted into Lake Ohrid in 1962 (Matzinger et al., 2006b).

\subsection{Gastropod sampling}

Gastropods from the Ohrid Basin were collected during seven field trips carried out between May 2003 and September 2009. Individuals were obtained by hand collecting from hard substrata in shallow waters or from stones and rocks lifted during snorkelling. Soft substratum and plant material was sieved. Deeper parts of Lake Ohrid down to $60 \mathrm{~m}$ were sampled using a triangular dredge from small boats or from the Hydrobiological Institute Ohrid (HBI) research vessel. Data on sampling locations were recorded with a GPS device and stored in a database in UTM format. All materials are deposited at the University of Giessen Systematics and Biodiversity Collection (UGSB). Species determination and nomenclature for gastropod samples follows Poliński (1929), Hubendick and Radoman (1959), Radoman (1983), Bodon et al. (2001), and Albrecht et al. (2006, 2008). A total of 284 samples from 224 different collecting points were obtained during field work. Note that our non-quantitative sampling does not allow for a statistical sound comparison of abundances of species. Thus we had to rely on strict presence/absence information of gastropod occurrences at each collecting point.

\subsection{Statistical analysis}

\subsubsection{Community composition and species richness}

Number of species, proportion of endemics, and species frequencies are important characteristics of ecosystems and local subdivisions, and may give clues as to the underlying abiotic constraints and evolutionary histories (Cooper and Purvis, 2010).

First, species collecting frequencies were estimated and species were classified into the categories rare, common, and frequent (see Sect. 3.1 for details). We used the rarefaction method for each species at each depth layer because of unbalanced collecting frequencies in the three different depth zones. Species frequency and standard deviation was obtained for the lowest number of collecting points $(N=34$, Deep Layer) by random site accumulation of one layer with 4999 permutations. To test for faunal subdivision of the different layers within the Ohrid Basin, we compared gastropod community compositions. Species compositions within a layer should be more similar than those of communities from different layers. Our hypothesis of distinct gastropod communities based on presence/absence data and BrayCurtis dissimilarities was tested by a one-factorial, permutational analysis of variance (PERMANOVA; Anderson, 2001) with 4999 permutations. For explorative data analysis, we used non-metric multidimensional scaling (NMDS; Kruskal and Wish, 1978) to transform similarity of species composition into an illustratable low-dimensional figure. Water depth and species richness of the collecting points were fitted to the ordination of the lake proper and statistical testing was achieved by 4999 permutations.

Differences in mean species richness of distinct layers were tested by a one-factorial PERMANOVA with 4999 permutations.

\subsubsection{Species co-occurrence}

Distinct gastropod communities might be the result of species aggregation or segregation. We used the $C$-score, which measures the degree of species co-occurrence (Stone and Roberts, 1990), standardized it to values between 1 (maximum segregation) and 0 (maximum aggregation), and classified all 2278 species pairs into 22 bins according to their $C$-score. A null model distribution of species pairs was calculated by permuting the presence/absence matrix 1000 times with the constraint of preserving species richness per collecting point and species occurrence frequency. Within one bin, species pairs were ordered according to their specific $Z$-score, which is $\left(C_{\text {observed }}-C_{\text {null model }}\right) \cdot \mathrm{StDev}^{-1}$. Subsequently, the number of species pairs $\left(N_{\text {species pairs observed }}-\right.$ $N_{\text {upper }} 95 \%$ CL of species pairs null model $)$ with the highest $Z$ score within every bin was calculated, which are considered to be aggregated. Detailed information about this Bayes CLcriterion, the most conservative one to detect co-occurrence, can be found in Gotelli and Ulrich (2010). The analysis was conducted with Pairs 1.1 (Ulrich, 2008).

\subsubsection{Analyses of spatial patterns}

Horizontal and vertical variations of species richness in Lake Ohrid were compared utilizing a heat map generated by the R package spatstat 1.17-5 (Baddeley and Turner, 2005). Three ESRI shapefiles (ESRI, Redlands California) were imported corresponding to the three bathymetrically different layers (see above). All collecting points with their species richness were allocated to the appropriate bathymetric layer and species richnesses among collecting points were interpolated using a Gaussian kernel weighting of species richnesses within a radius of $2 \mathrm{~km}$.

\subsubsection{Explanatory variables of community composition}

Variance partitioning (see Peres-Neto et al., 2006 for methological details) have been shown to be an adequate method to assess whether niche or neutral based processes drive biodiversity (Smith and Lundholm, 2010). In order to explain the similarity of gastropod communities in Lake Ohrid, we partitioned the variance into two fractions, one accounting for niche based and one for neutral processes. Niche processes summarize the influence of environmental factors and were classified into a fraction of three large scale predictors like collecting depth and into a fraction of eigth small 
Table 1. Environmental and spatial predictors explaining the variance of 156 gastropod communities of Lake Ohrid. All environmental predictors were arcsin- or z-standardised and chosen by stepwise selection using a Bray-Curtis distance based redundancy analysis. Note that adding predictors to our model was always carried out with $p<0.05$ and only the significance level for dropping the predictor is given.

\begin{tabular}{|c|c|c|c|c|}
\hline Predictor & Type & Source & $\alpha$ & Sum $R_{\mathrm{adj}}^{2}$ \\
\hline$C / N$ & continuous & Vogel et al. (2010) & NS & \\
\hline Total inorganic carbonate & continuous & Vogel et al. (2010) & NS & \\
\hline Silt & continuous & Vogel et al. (2010) & NS & \\
\hline Geological age & categorical ordered & Hoffmann et al. (2010) & NS & \\
\hline Collecting depth & continuous & This study & $* * *$ & 0.226 \\
\hline Substrate forming bedrock & categorical & European Soil Portal (2008) & $*$ & 0.261 \\
\hline Collecting depth:Slope & continuous & This study & $* * *$ & 0.284 \\
\hline PCNM2 & continuous & & $* * *$ & 0.303 \\
\hline PCNM1 & continuous & & $* * *$ & 0.320 \\
\hline PCNM3 & continuous & & $* * *$ & 0.333 \\
\hline PCNM8 & continuous & & $* *$ & 0.345 \\
\hline Slope & continuous & $\begin{array}{l}\text { Nearest neighbour } \\
\text { interpolation of ArcMAP } \\
9.3 \text { (ESRI, Redlands } \\
\text { California) using } 10000 \\
\text { equidistant points of } \\
\text { isobaths map (Albrecht and } \\
\text { Wilke, 2008) }\end{array}$ & $* * *$ & 0.354 \\
\hline PCNM7 & continuous & & $* *$ & 0.362 \\
\hline Chlorophyll- $a$ & continuous & Vogel et al. (2010) & ** & 0.370 \\
\hline Total organic carbonate & continuous & Vogel et al. (2010) & $* * *$ & 0.378 \\
\hline PCNM59 & continuous & & $*$ & 0.385 \\
\hline PCNM6 & continuous & & $*$ & 0.391 \\
\hline
\end{tabular}

NS: not significant, $* p<0.1, * * p<0.05, * * * p<0.01, * * * * p<0.001$

scale variables such as chlorophyll- $a$. All tested environmental predictors are shown in Table 1. Until recently, an analysis of the contribution of the third fraction, neutral processes, was hampered by the limited quality of variables that describe the distribution of community similarity via spatial autocorrelation (Smith and Lundholm, 2010). These spatial descriptors are now obtained by principal coordinates of neighbouring matrices (PCNM; Borcard and Legendre, 2002). This approach computes a diagonalized matrix of Euclidean distances for the point coordinates by truncating all pairwise distances above a fourfold threshold value (Borcard and Legendre, 2002). All collecting points above this value are not considered as neighbours and may receive different community similarities in consecutive simulations. According to Blanchet et al. (2008), we first tested for a significant $(\alpha<0.05)$ prediction of the full model with all PCNMs with 4999 permutations. We used a constrained ordination (distance based redundancy analysis; db-RDA) because it allows the use of non-euclidean distances (Legendre and Anderson, 1999) like the here utilized Bray-Curtis dissimilarities of gastropod communities. Moreover, though this analysis is strictly linear, it allows for the utilization of interaction terms of explanatory variables. Then, significant environment and spatial variables were selected via stepwise model selection, which extended the forward selection suggested by Blanchet et al. (2008). This approach utilizes a double stop criterion: p-values of variables obtained by a maximum of 999 permutations and the adjusted coefficient of determination $\left(R_{\text {adj }}^{2}\right)$ of the model, which penalizes additional variables and stops if additional variables do not increase the $R_{\text {adj }}^{2}$ any further (Blanchet et al., 2008).

According to Peres-Neto et al. (2006), the partitioning of variance into fractions should be unbiased, that is, fractions with more degrees of freedom have to be penalized. The resulting $R_{\text {adj }}^{2}$ allows for a direct comparison of predictor fractions. In order to obtain non-negative values for shared fractions and to perform the recommended redundancy analysis (Peres-Neto et al., 2006), we utilized a square root transformation of the semi-metric Bray-Curtis dissimilarities to meet the assumption of strict Euclidian distances (Legendre and Anderson, 1999).

All analyses were carried out using the R 2.12 statistical environment (R Development Core Team, 2009) and the vegan 1.18-20 package (Oksanen et al., 2011). 


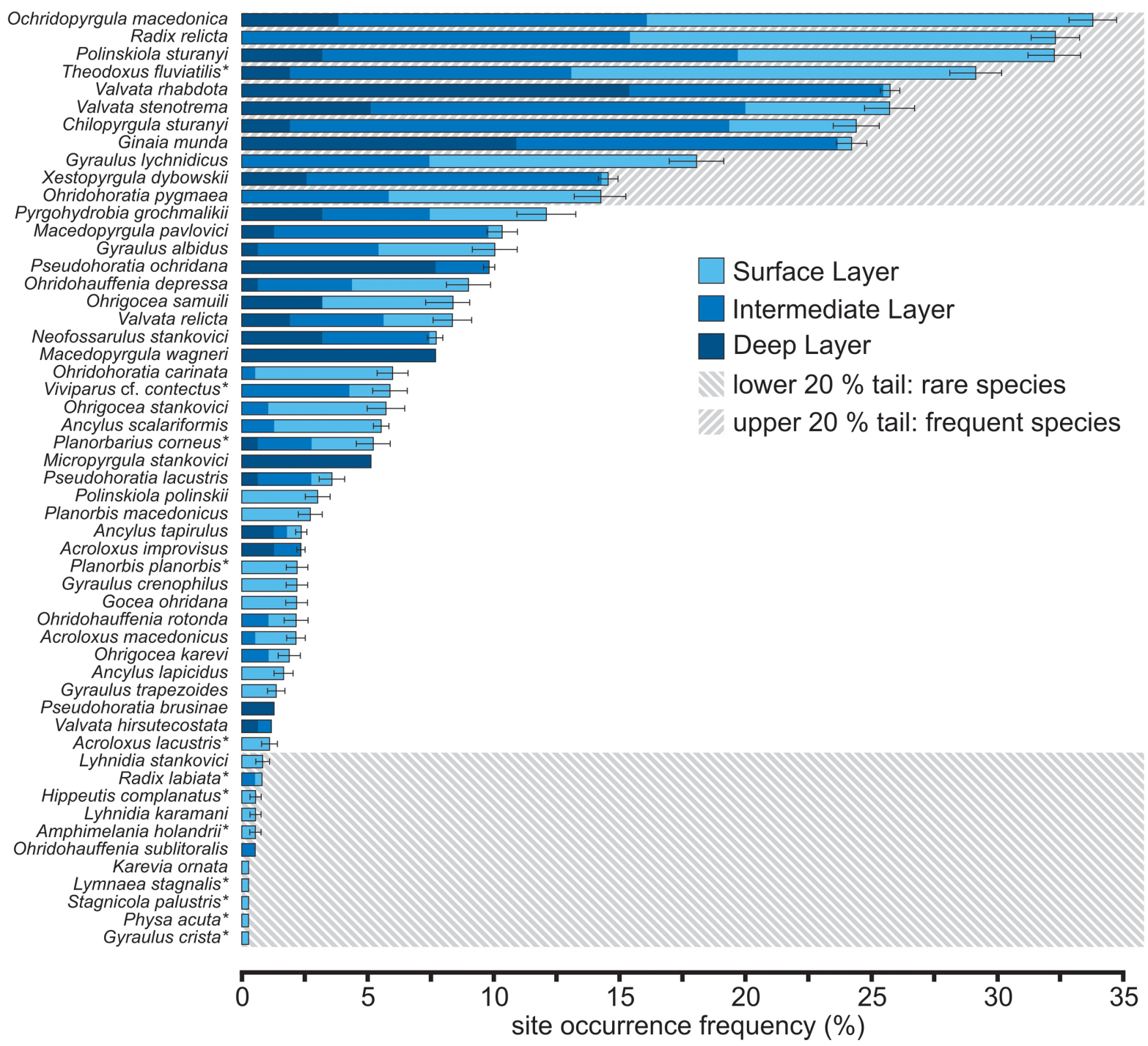

Fig. 2. Plot of frequency and standard deviation of species sites occurrence of gastropod species found in Lake Ohrid. Depth layers are colour-coded and widespread species are marked by asterisks.

\section{Results}

\subsection{Species occurrence frequency and endemism}

A total of 68 gastropod species was found in the Ohrid Basin with 50 of them $(73.5 \%)$ being endemic. Following the species based rarefaction of the lake species (Fig. 2), we applied the criteria of Williams et al. (1996) to classify taxa according to frequency. Those species that account for the top $20 \%$ quantile were considered to be frequent species and the same proportion at the lower tail as rare. Frequent species were found at up to one third of all sampling points; common species at $1-12 \%$ and the 11 rare species at less than $1 \%$ of all sites. Moreover, most of the rare gastropod species were non-endemics. No gastropod specimens were found in Lake Ohrid below $60 \mathrm{~m}$ water depth or in the high mountain springs of its basin.

\subsection{Community composition and species richness}

Explorative analyses of gastropod community similarities showed differences both within the Ohrid Basin (Fig. 3a) and within Lake Ohrid itself (Fig. 3b). The two-dimensional ordination of all collecting points revealed a Kruskal stress value of 19.39, indicating marginal congruence with the original data structure (Kruskal and Wish, 1978). A partitioning into Lake Ohrid, feeder springs, lotic waters, and northeastern/northwestern springs was supported by a significant zonation effect on community composition $\left(F_{3,220}=21.48\right.$, $P<0.001)$. The three-dimensional NMDS of the Lake Ohrid communities had a stress value of 15.4. Vector fitting showed a highly significant correlation between ordination structure and both collecting depth $\left(R^{2}=0.79, P<\right.$ $0.001)$ and species richness $\left(R^{2}=0.48, P<0.001\right)$. The 

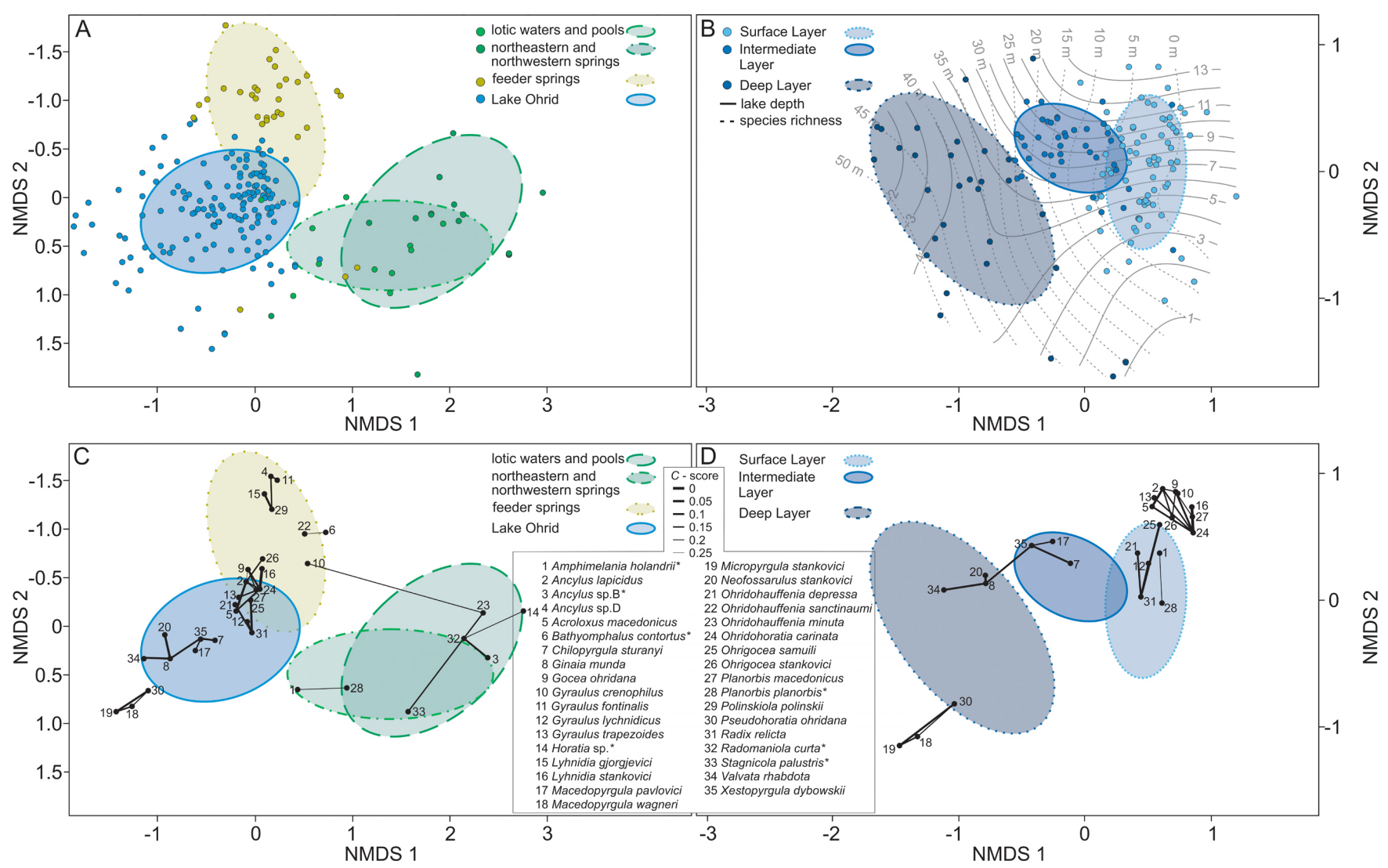

Fig. 3. NMDS plots of gastropod communities (Bray-Curtis dissimilarity). (A) Two-dimensional solution within the Ohrid Basin showing little similarity among horizontal zones. (B) Vector fitting of collecting depth and species richness for the three-dimensional solution within Lake Ohrid showing community turnover correlated with collecting depth. (C) Species joint plots of the ordination within the Ohrid Basin, and (D) within Lake Ohrid indicating non-random co-occurrence of species by line connection. Widespread species are marked by asterisks and line widths correspond to the degree of species co-occurrence.

differences between species assemblages in the three lake layers were also supported by a significant PERMANOVA result $\left(F_{2,153}=29.18, P<0.001\right)$.

The different layers are characterized by different numbers of widespread, endemic, and layer endemic gastropod species (Fig. 4a). The three different layers of Lake Ohrid harbour more species and endemics than outside water bodies. The northeastern and northwestern springs as well as the feeder-springs revealed the highest proportion of point endemic species.

Species richness (Fig. 4b) differed among the zones of the Ohrid Basin $\left(F_{3,220}=15.68, P<0.001\right)$ as well as among the depth layers of the lake $\left(F_{2,153}=19.73, P<0.001\right)$. The Intermediate Layer, for example, showed the highest alpha diversity with a mean of $8.8 \pm 1.4$ gastropods per collecting point, whereas the lotic waters and northern springs harboured the lowest number of species $(2.5 \pm 0.6$ and $3 \pm 0.8$, respectively).

\subsection{Species co-occurrence}

Out of 2278 species pairs analysed, 31 showed a higher cooccurrence frequency than expected by chance. All of these species pairs occurred in the same zone or layer. (Fig. 3c and d). Of these 31 pairs, 30 pairs involved endemic species and one pair Palaearctic widespread species. No pair of species recently invading Lake Ohrid Basin (i.e. not known from previous studies) and endemic gastropods could be detected.

\subsection{Spatial analysis}

Species richness maps (Fig. 4c and d) showed a relatively homogeneous distribution of gastropod species in the Deep and Intermediate Layer, whilst the highest variation occurred in the Surface Layer.

Acknowledging that we did not apply a statistical model for identifying places with elevated degrees of endemic biodiversity ("hotspots" sensu Prendergast et al., 1993), candidate places as shown in Fig. 4d are the area around Veli Dab (southeastern shore) of the Surface Layer as well as areas of 

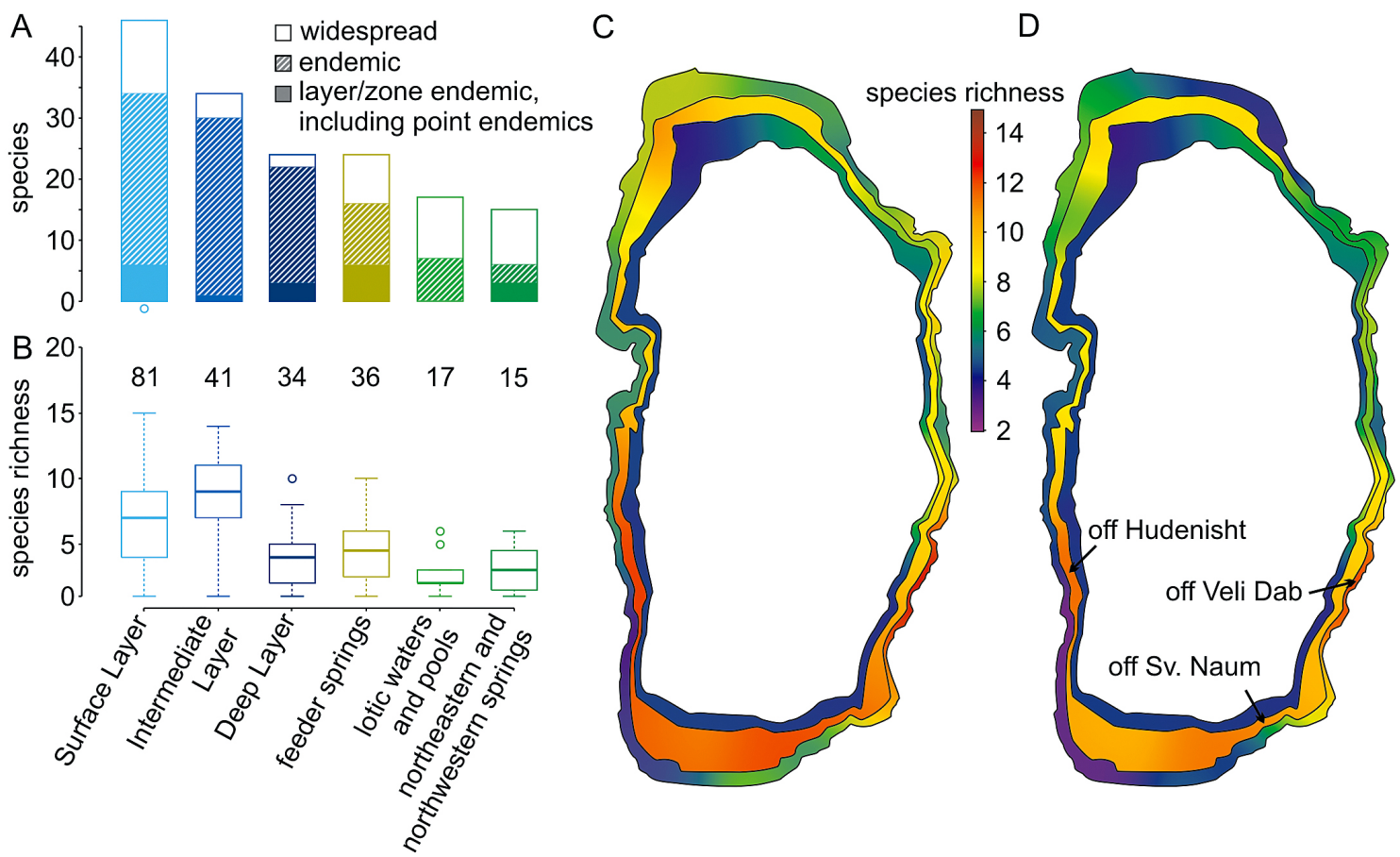

Fig. 4. Zonation and layer-specific analyses of gastropod species richnesses in the Ohrid Basin. (A) Bar plots of species compositions. (B) Quartile box plots of species richness including median, upper and lower quartiles (boxes) and 1.5 interquartile range whiskers (numbers above plots indicate the total number of species in the respective layer/zone). (C) Species richness map based on all species. (D) Species richness map based on endemics. Candidate hotspots of endemic species richness are indicated by arrows. Because of the strong slope at the eastern and western tectonic faults, the depth layers could have a width of less than $10 \mathrm{~m}$, and were thus stretched for better visibility.

the Intermediate Layer off Sv. Naum (southern shore) and off Hudenisht (southwestern shore).

\subsection{Explanatory variables of community composition}

A total of 75 PCNMs were constructed and the significance test of the full spatial modal was passed $(P<0.05)$. Altogether, the significant spatial (Fig. 5) and environmental variables explained $39.1 \%$ of the variance of gastropod species composition of Lake Ohrid (Table 1). The variance inflating factors of all variables were lower than the critical heuristic value of 10 , indicating that they are not correlated. The environmental variables explained more than double the variance than spatial predictors (Fig. 6). Moreover, large scale environmental variables had a higher explanatory power than small scale factors, which in turn contributed less to the similarity of gastropod communities than purely spatial predictors. In general, the shared fractions among our predictor classes explain only a small proportion of variance of the gastropod assemblages.

\section{Discussion}

Our results suggest the existence of distinct gastropod communities both within the different zones of the Ohrid Basin and within the different depth layers of the lake. These communities seem to be explained by environmental variables with a significant contribution of neutral processes. The rivers and northeastern and northwestern springs are species poor, the southern feeder-springs show moderate mean species richness, and all zones of the lake proper are species rich, except for the Deep Layer. However, all three depth layers are almost exclusively inhabited by endemics. While the Intermediate Layer has the highest mean alpha diversity, the highest variation of alpha diversity can be found in the Surface Layer.

\subsection{Endemism and species frequency}

The total number of 68 gastropod species and the total number of 50 endemic species found in our study are only slightly lower than those reported by Radoman (1985), that is, 72 and 56 species, respectively. It should be noted that the numbers published by Radoman are based on approximately 30 years of field work. The six endemic species not rediscovered in our recent sampling are known to have been described from empty shells, are only sporadically released 

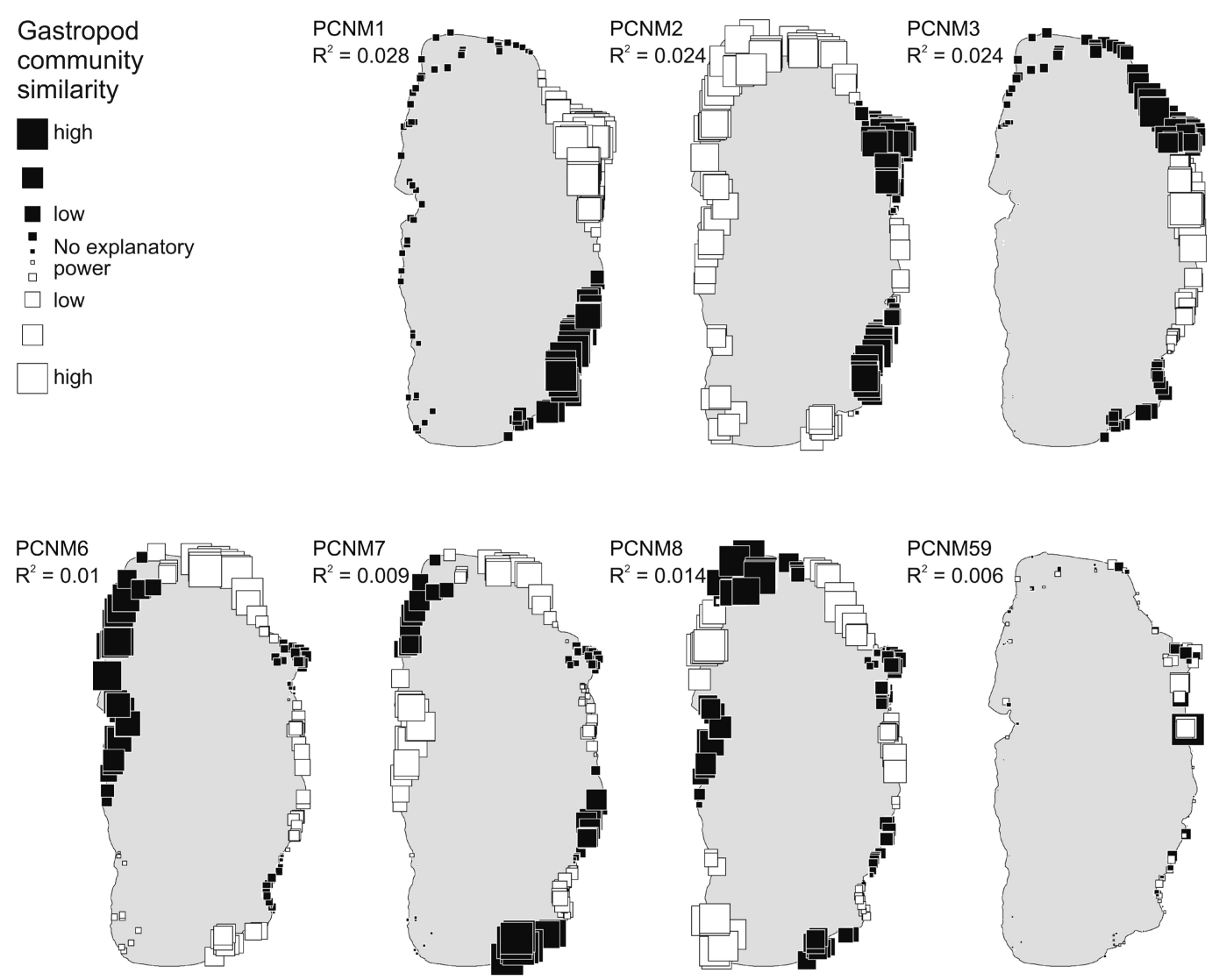

Fig. 5. Spatial prediction of community similarities of Lake Ohrid utilizing PCNM eigenfunctions. Six broad and one fine scale vectors explain $11.5 \%$ of the variation of gastropod communities. Within each eigenfunction, groups of equally-coloured squares indicate similar gastropod communities. Increasing square size shows higher similarity (note that small squares may not have sufficient explanatory power). Higher eigenfunctions represent increasingly smaller spatial scale predictions. Therefore, the frequency of alternating groups of black and white squares increases.

from subterranean springs, or are rare Deep Layer species. Accordingly, the rate of endemism revealed in our study $(73.5 \%)$ is also lower than the $78 \%$ suggested by Radoman (1985). In addition, we collected three widespread species previously unknown to the Ohrid Basin, which further reduces the rate of endemicity. On the other hand, recent molecular studies (Albrecht et al., 2006, 2008) revealed the existence of two new cryptic feeder spring species. Albrecht and Wilke (2008) emphasized the lack of knowledge concerning the evolutionary history of many taxa and that future molecular studies will probably result in the discovery of more new endemic species in Lake Ohrid (also see Schultheiß et al., 2008 for a molecular study on pea-clams and Marková et al., 2010 for cryptic phylogenetic subdivision in a cyprinid species). In terms of the total number of endemic gastropod species, Lake Ohrid is only outnumbered by ancient lakes Baikal, Tanganyika and the Malili lakes. However, taking surface area into account by applying the normalized endemic species area index (Albrecht and Wilke, 2008), Lake Ohrid surpasses other ancient lakes in terms of endemic gastropod biodiversity (Albrecht et al., 2009).
In Lake Ohrid, a high proportion of gastropod species are endemics (Fig. 4a), many of them being common (Fig. 2) and relatively unconfined regarding their depth preferences. Interestingly, the non-endemics are almost exclusively rare species and occur mostly in the Surface Layer. In fact, there appears to be a positive correlation between species frequency and depth range.

In contrast to previous reports (e.g., Hadžišče, 1956; Stanković, 1960; Radoman, 1983), an obvious shift in the frequency of endemic species occurrences at sites could not be detected. However, a shift in species depth range appears to be possible. Whereas we were unable to find specimens below depths of $60 \mathrm{~m}$, occurrences at up to $100 \mathrm{~m}$ depth were reported by Radoman (1985).

Moreover, an increasing number of widespread species are observed living in areas of the highest anthropogenic pressure in the western (Lin Peninsula) and northeastern (Ohrid Bay, Sateska Estuary) parts of the lake (Fig. 4d, also see Kostoski et al., 2010). However, no community disassembling due to either widespread-/widespread- or widespread/endemic species pairs could yet be observed (Fig. 3c and d). 


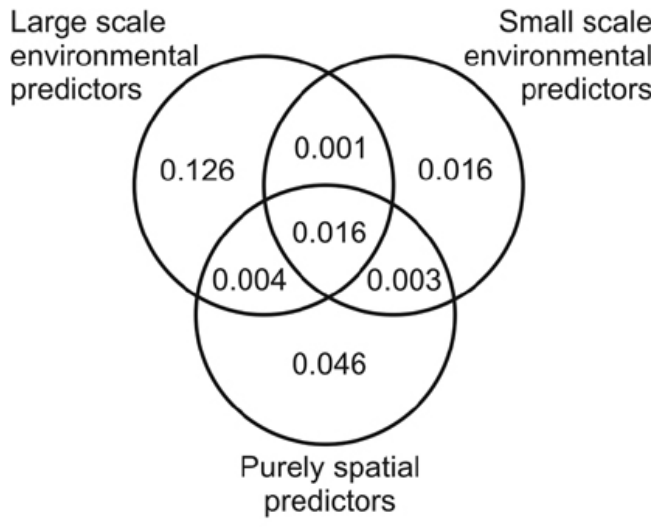

unexplained $=0.789$

Fig. 6. Venn-diagram showing the partitioning of the explained variance of gastropod community compositions in Lake Ohrid into fractions of predictors and their combinations. The figure indicates that large scale environmental predictors (i.e. collecting depth, slope, and collecting depth:slope) alone can explain most of the similarity between gastropod communities. This is followed by purely spatial predictors (i.e. 7 PCNMs) and small scale environmental predictors (i.e. chlorophyll- $a$, total organic carbonate, and substrate forming bedrock). Note that the square root of the community dissimilarity measure was used. Therefore the adjusted explained variance is lower than given in Table 1. For detailed explanations see the Material and method section.

This is probably due to the only recent onset of eutrophication of Lake Ohrid (Matzinger et al., 2006a) and the still limited invasion of Lake Ohrid by additional widespread species (Fig. 2). In contrast to Lake Ohrid, an increase in abundances of widespread gastropod species at the expense of endemic species has been shown in ancient Lake Malawi (Genner et al., 2004), the Caspian Sea (Grigorovich et al., 2002), and potential ancient lakes in the Balkans (Albrecht et al., 2009).

\subsection{Faunal subdivision of the Ohrid Basin}

In general, little faunal overlaps were observed among different zones or layers (Fig. 3). Hence, our results suggest, on the one hand, a good separation of lake gastropod communities from the surrounding watershed, whilst, on the other hand, a fair degree of separation among communities of feeder springs versus northwestern/northeastern springs and lotic waters (Fig. 3a). As originally proposed by Boss (1978) and refined by Wilke et al. (2010), a common feature of ancient lakes is eco-insularity. Accordingly, well adapted ancient lake organisms may out-compete most invading species but are probably inferior outside the native lake. Hence, little faunal overlap is expected in the case of eco-insularity. The recent lake shore, however, may not necessarily constitute the "island" border and there are examples showing effects of eco-insularity not only at the lake but also at the watershed level (Glaubrecht and Rintelen, 2008; Schultheiß et al.,
2009). In Lake Ohrid, the situation appears to be more complex. Whilst we do see eco-insularity on a basin scale (Albrecht et al., 2009), we also see evidence for patterns within the basin: eco-insularity of the lake proper and eco-insularity of the feeder-springs.

While these horizontal zones are well reflected in a distinct species distribution, the differentiation of gastropod communities relative to vertical depth layers is less pronounced. This may be due to less distinct transitions of environmental factors among the different layers of Lake Ohrid. However, spatial gradients of sediment features have been shown before (Vogel et al., 2010) and different substrata are likely to affect species richness and distribution (Kershner and Lodge, 1990; Michel, 1994). In fact, the present study strongly suggests that today's gastropod composition of Lake Ohrid was mainly driven by environmental conditions with a partial but significant contribution of purely neutral mechanisms. The similarity of gastropod communities of Lake Ohrid is mostly explained by large scale factors like water depth, resulting in a high turnover of species assemblages (Table 1). Interestingly, the neutral drivers of biodiversity showed a marginal higher explanatory power of community composition than small scale environmental factors. According to Legendre et al. (2005) and Gotelli and McGill (2006), these neutral processes suggest a limited dispersal of species or the evolution of new species in spatially distinct areas, thus the evolutionary histories of species appears to matters and it is reflected in their distribution in Lake Ohrid.

\subsection{Hotspots of species richness}

The Intermediate Layer showed both the highest number of species per collecting point but also the lowest number of species exclusively restricted to a single depth layer. Whereas annual water level fluctuation and wave action restrict plant and bacteria growth in the Surface Layer (Stanković, 1960), the Intermediate Layer is relatively undisturbed, yet enough light reaches this part (Stanković, 1960). Therefore, this photic zone is known to be the most bioproductive layer in Lake Ohrid (Tocko and Sapkarev, 1978). Similar patterns of elevated species richness in Intermediate Layers were observed in ancient lakes Tanganyika (Michel, 1994), Baikal (Sitnikova, 2006) and Titicaca (Dejoux, 1992). In contrast, the Caspian Sea shows a rather continuous decline of species richness and density with increasing water depth (Parr et al., 2007). However, elevated species richness in shallow parts is suggested to be a general feature of ancient lakes (Martens, 1997). No comprehensive species richness study of other taxa has been conducted in Lake Ohrid so far. Analyses of phytoplankton and Chironomidae abundances suggest a similar peak value at the Intermediate Layer, whereas Oligochaeta, Amphipoda and especially Ostracoda show their highest densities in deeper waters (Stanković, 1960; Mikulič and Pljakic, 1970). 
Interestingly, the species richness map (Fig. 4c) shows relatively uniform distributions of alpha diversity for the Deep and Intermediate Layers. The Surface Layer, however, is characterized by a rather heterogeneous species richness distribution. Of the three suggested biodiversity hotspots, the area around Veli Dab, appears to be outstanding in terms of point endemism. This hotspot, comprising an area of less than $1 \mathrm{~km}^{2}$, exclusively harbours $>10 \%$ of Lake Ohrids' endemic gastropod biodiversity (Fig. 4a; also see Wilke and Albrecht, 2007), including most point endemics of Lake Ohrid, which are highly aggregated (Fig. 3d). These taxa are known to require a specific environment, the so-called "littoral interlithon", that is, a patchy system of porous stones or rocks often associated with sublacustrine spring fields (e.g., Hadžišče, 1956; Albrecht and Wilke, 2008).

\section{Conclusions}

This spatially comprehensive study of a large taxon revealed interesting patterns of biodiversity in the Ohrid Basin. The total number of 68 species of gastropods here reported with $73.5 \%$ of them being endemic does not substantially differ from the numbers generated decades ago. We also did not find significant differences in the frequency of species occurrences at sites. We do, however, see a moderate trend indicating a decrease in endemic species and an increase of widespread species. Interestingly, many endemic species are very common (Fig. 2) and relatively unconfined regarding their depth preferences. In contrast, non-endemic species are mostly rare species, typically being restricted to limited areas of the surface layer. However, so far, community disintegration due to widespread species invading Lake Ohrid could not be shown.

Little faunal overlap was observed in the NMDS analysis, indicating strong effects of eco-insularity for the Ohrid Basin. Moreover eco-insularity appears to act on two spatial scales - on the level of the whole watershed and on the level of the lake proper/feeder springs.

Variation of community assemblages is likely to be explained by hierarchically structured effects acting on different scales. Large scale effects such as type of water body and lake depth do, indeed, cause broad differences, while small scale effects like environmental gradients typically cause minor differences in biodiversity distributions on a smaller spatial scale. However, a significant proportion of community variation seems to be driven by the dispersal capacity and evolutionary history of the species.

Alpha diversities of the Deep and Intermediate Layers show relatively uniform spatial distributions. In contrast, only the Surface Layer is characterized by heterogeneous species richnesses. Moreover, all point endemics of the lake proper reported in our study are to be found in a single biodiversity hotspot at the rocky southeastern shore. This site harbours $>10 \%$ of Lake Ohrids' endemic gastropod species.
While our study shows a strong correlation between the hydrological features of the Ohrid Basin and the spatial distribution of gastropod diversity, future studies should focus on the underlying evolutionary processes generating the extraordinary high degree of biodiversity within Lake Ohrid.

Acknowledgements. We are grateful to our colleagues at the Hydrobiological Institute Ohrid for their valuable support. D. Georgiev (Ohrid) supported our field work with his immense local expertise. Sincere thanks are given to all student colleagues for making the field work a pleasant experience and to S. Nachtigall for her assistance in the laboratory. The referees S. Giokas, M. Harzhauser and P. Solymos provided valuable comments that helped improving the manuscript. This research was supported by DFG grants to TW (WI 1902/8-1) and CA (AL 1076/3-1).

Edited by: B. Wagner

\section{References}

Abell, R., Thieme, M. L., Revenga, C., Bryer, M., Kottelat, M., Bogutskaya, N., Coad, B., Mandrak, N., Balderas, S. C., Bussing, W., Stiassny, M. L. J., Skelton, P., Allen, G. R., Unmack, P., Naseka, A., Ng, R., Sindorf, N., Robertson, J., Armijo, G., Higgins, J. H., Heibel, T. J., Wikramanayake, E., Olson, D., López, H. L., Reis, R. E., Lundberg, J. G., Pérez, M. H. S., and Petry, P.: Freshwater ecoregions of the world: a new map of biogeographic units for freshwater biodiversity conservation, Bioscience, 58(5), 403-414, 2008.

Albert, C. H., Yoccoz, N. G., Edwards Jr., T. C., Graham, C. H., Zimmermann, N, E., and Thuiller, W.: Sampling in ecology and evolution - bridging the gap between theory and practice, Ecography, 33, 1028-1037, 2010.

Albrecht, C. and Wilke, T.: Ancient Lake Ohrid: biodiversity and evolution, Hydrobiologia, 615, 103-140, 2008.

Albrecht, C., Trajanovski, S., Kuhn, K., Streit, B., and Wilke, T.: Rapid evolution of an ancient lake species flock: Freshwater limpets (Gastropoda: Ancylidae) in the Balkan Lake Ohrid, Org. Divers. Evol., 6, 294-307, 2006.

Albrecht, C., Wolff, C., Glöer, P., and Wilke, T.: Concurrent evolution of ancient sister lakes and sister species: the freshwater gastropod genus Radix in lakes Ohrid and Prespa, Hydrobiologia, 615, 157-167, 2008.

Albrecht, C., Hauffe, T., Schreiber, K., Trajanovski, S., and Wilke, T.: Mollusc biodiversity and endemism in the potential ancient lake Trichonis, Greece, Malacologia, 51(2), 357-375, 2009.

Albrecht, C., Vogel, H., Hauffe, T., and Wilke, T.: Sediment core fossils in ancient Lake Ohrid: testing for faunal change since the Last Interglacial, Biogeosciences, 7, 3435-3446, doi:10.5194/bg-7-3435-2010, 2010.

Anderson, M. J.: A new method for non-parametric multivariate analysis of variance, Austral Ecol., 26, 32-46, 2001.

Baddeley, A. and Turner, R.: Spatstat: an R package for analyzing spatial point patterns, J. Stat. Softw., 12(6), 1-42, ISSN 15487660, www.jstatsoft.org, 2005.

Belmecheri, S., Namiotko, T., Robert, C., von Grafenstein, U., and Danielopol, D. L: Climate controlled ostracod preservation in Lake Ohrid (Albania, Macedonia), Palaeogeogr. Palaeocl., 277, 236-245, 2009. 
Blanchet, F. G, Legendre, P., and Borcard, D.: Forward selection of explanatory variables, Ecology, 89(9), 2623-2632, 2008.

Bodon, M., Manganelli, G., and Giusti, F.: A survey of the European valvatiform hydrobiid genera with special reference to Hauffenia Pollonera, 1898 (Gastropoda: Hydrobiidae), Malacologia, 43(1-2), 103-215, 2001.

Borcard, D. and Legendre, P.: All-scale spatial analysis of ecological data by means of principal coordinates of neighbour matrices, Ecol. Model., 153, 1826-1832, 2002.

Boss, K. J.: On the evolution of gastropods in ancient lakes, in: Pulmonates, vol. 2a, Systematics, Evolution and Ecology, edited by: Fretter, V. and Peake, J., Academic Press, London, New York, San Francisco, 385-428, 1978.

Buckley, L. B. and Jetz, W.: Linking global turnover of species and environment, P. Natl. Acad. Sci. USA, 105(46), 17836-17841, doi:10.073/pnas.0803524105, 2008.

Cohen, A. S.: Extinction in ancient lakes: Biodiversity crises and conservation 40 years after J. L. Brooks, Arch. Hydrobiol., 44, 451-479, 1994.

Cohen, A. S., Stone, J. R., Beuning, K. R. M., Park, L. E., Reintal, P. N., Dettman, D., Scholz, C. A., Johnson, T. C., King J. W., Talbot, M. R., Brown, E. T., and Ivory, S. J.: Ecological consequences of early Late Pleistocene megadroughts in tropical Africa, P. Natl. Acad. Sci. USA, 104, 16422-16427, doi:10.1073/pnas.0703873104, 2007.

Cooper, N. and Purvis, A.: Body size evolution in mammals: complexity in tempo and mode, Am. Nat., 175(6), 727-738, 2010.

Dejoux, C.: The benthic populations: distribution and seasonal variations, in: Lake Titicaca a synthesis of limnological knowledge, edited by: Dejoux, C. and Iltis, A., Kluwer Academic Publishers, The Netherlands, 383-401, 1992.

Diniz-Filho, J. A. F. and Bini, L. M.: Modelling geographical patterns in species richness using eigenvector-based spatial filters, Global Ecol. Biogeogr., 14, 177-185, 2005.

European Soil Portal: European Commission Joint Research Centre, Institute for Environment and Sustainability, http://eusoils. jrc.ec.europa.eu, last access: 25 October 2008.

Gaston, K. J.: Global patterns of biodiversity, Nature, 405, 220227, 2000.

Gaston, K. J. and Spicer J. I.: Biodiversity: an introduction, 2nd edn., Blackwell Science Ltd, Malden, 191 pp., 2005.

Genner, M. J., Michel, E., Erpenbeck, D., de Voogd, N., Witte, F., and Pointier, J. P.: Camouflaged invasion of Lake Malawi by an oriental gastropod, Mol. Ecol., 13, 2135-2141, doi:10.1111/j.1365-294x.2004.02222.x, 2004.

Glaubrecht, M. and von Rintelen, T.: The species flocks of lacustrine gastropods: Tylomelania on Sulawesi as models in speciation and adaptive radiation, Hydrobiologia, 615, 181-199, 2008.

Gotelli, N. J. and McGill, B. J.: Null versus neutral models: what's the difference?, Ecography, 29, 793-800, doi:10.1111/j.2006.0906-7590.04714.x, 2006.

Gotelli, N. J. and Ulrich, W.: The empirical Bayes approach as a tool to identify non-random species associations, Oecologia, 162, 463-477, doi:10.1007/s00442-009-1474-y, 2010.

Grigorovich, I. A., Therriaul, T., and Maclsaac, H. J.: History of aquatic invertebrate invasions in the Caspian Sea, Biol. Invasions, 5, 103-115, 2002.

Hadžišće, S.: II. Beitrag zur Kenntnis der Gastropodenfauna des Ohridsees. Beschreibung der bis jetzt unbekannten Schnecken und Beispiele der Speciation bei den Gastropoden des Ohridsees, Recueil des Traveaux, Station Hydrobiologique Ohrid, 4, 57-107, 1956.

Harzhauser, M. and Mandic, O.: Neogene lake systems of Central and South-Eastern Europe: faunal diversity, gradients and interrelations, Palaeogeogr. Palaeocl., 260, 417-434, 2008.

Hauswald, A. K., Albrecht, C., and Wilke, T.: Testing two contrasting evolutionary patterns in ancient lakes: species flock versus species scatter in valvatid gastropods of Lake Ohrid, Hydrobiologia, 615, 169-179, 2008.

Herder, F., Nolte, A. W., Pfaender, J., Schwarzer, J., Hadiaty, R. K., and Schliewen, K.: Adaptive radiation and hybridization in Wallace's dreamponds: evidence from sailfin silversides in the Malili Lakes of Sulawesi, P. Roy. Soc. Lond. B Bio., 273, 22092217, doi:10.1098/rspb.2006.3558, 2006.

Hof, C., Brändle, M., and Brandl, R.: Latitudinal variation of diversity in European freshwater animals is not concordant across habitat types, Global Ecol. Biogeogr., 17, 539-546, 2008.

Hoffmann, N., Reicherter, K., Fernández-Steeger, T., and Grützner, C.: Evolution of ancient Lake Ohrid: a tectonic perspective, Biogeosciences, 7, 3377-3386, doi:10.5194/bg-7-3377-2010, 2010.

Holtvoeth, J., Vogel, H., Wagner, B., and Wolff, G. A.: Lipid biomarkers in Holocene and glacial sediments from ancient Lake Ohrid (Macedonia, Albania), Biogeosciences, 7, 3473-3489, doi:10.5194/bg-7-3473-2010, 2010.

Hubendick, B. and Radoman, P.: Studies on the Gyraulus species of Lake Ochrid, Morphology, Ark. Zool., 12(16), 223-243, 1959.

Kashiwaya, K., Sakai, H., Ryugo, M., Horii, M., and Kawai, T.: Long-term climato-limnological cycles found in a 3.5million-year continental record, J. Paleolimnol., 25(3), 271-278, doi:10.1023/A:1011122808544, 2001.

Kershner, M. W. and Lodge, D. M.: Effects of substrate architecture on aquatic gastropod-substrate associations, J. N. Am. Benthol. Soc., 9(4), 319-326, 1990.

Kostoski, G., Albrecht, C., Trajanovski, S., and Wilke, T.: A freshwater biodiversity hotspot under pressure - assessing threats and identifying conservation needs for ancient Lake Ohrid, Biogeosciences, 7, 3999-4015, doi:10.5194/bg-7-3999-2010, 2010.

Kruskal, J. B. and Wish, M.: Multidimensional scaling, Sage Publications, Beverly Hills, California, 93 pp., 1978.

Kunz, M.: Karst springs of Lake Ohrid, Master thesis, Swiss Federal Institute of Technology (ETH), Zürich, 2006.

Legendre, P. and Anderson, M. J.: Distance-based redundancy analysis: testing multispecies responses in multifactorial ecological experiments, Ecol. Monogr., 69, 1-24, 1999.

Legendre, P., Borcard, D., and Peres-Neto, P. R.: Analyzing beta diversity: partitioning the spatial variation of community composition data, Ecol. Monogr., 75, 435-450, 2005.

Lindhorst, K., Vogel, H., Krastel, S., Wagner, B., Hilgers, A., Zander, A., Schwenk, T., Wessels, M., and Daut, G.: Stratigraphic analysis of lake level fluctuations in Lake Ohrid: an integration of high resolution hydro-acoustic data and sediment cores, Biogeosciences, 7, 3531-3548, doi:10.5194/bg-7-3531-2010, 2010.

Marková, S., Šanda, R., Crivelli, A., Shumka, S., Wilson, I. F., Vukić, J., Berrebi, P., and Kotlík, P.: Nuclear and mitochondrial DNA sequence data reveal the evolutionary history of Barbus (Cyprinidae) in the ancient lake systems of the Balkans, Mol. Phylogenet. Evol., 55(2), 488-500, doi:10.1016/j.ympev.2010.01.030, 2010. 
Martens, K.: Speciation in ancient lakes (review), Trends Ecol. Evol. (Amst), 12, 177-182, 1997.

Matzinger, A., Jordanoski, M., Veljanoska-Sarafiloska, E., Sturm, M., Müller, B., and Wüest, A.: Is Lake Prespa jeopardizing the ecosystem of ancient Lake Ohrid?, Hydrobiologia, 553, 89-109, 2006a.

Matzinger, A., Spirkovski, Z., Patceva, S., and Wüest, A.: Sensitivity of ancient Lake Ohrid to local anthropogenic impacts and global warming, J. Great Lakes Res., 32, 158-179, 2006 b.

Michel, E.: Why snails radiate: a review of gastropod evolution in long-lived lakes, both recent and fossil, in: Speciation in Ancient Lakes, edited by: Martens, K., Godderis, B., and Coulter, G., Arch. Hydrobiol., 44, 285-317, 1994.

Mikulič, F. and Pljakic, M. A.: Die Merkmale der Qualitativen Distribution der endemischen Candonaarten im Ohridsee, Ekologija, 5(1), 101-115, 1970.

Oksanen, J., Blanchet, F. G., Kindt, R., Legendre, P., O'Hara, R. G., Simpson, G. L., Solymos, P., Stevens, M. H. H., and Wagner, H.: vegan: Community Ecology Package, $\mathrm{R}$ package version 1.1820., http://R-Forge.R-project.org/projects/vegan/, last access: 4 January 2011.

Parr, T. D., Tait, R. D., Maxon, C. L., Newton III, F. C., and Hardin J. L.: A descriptive account of benthic macrofauna and sediment from an area of planned petroleum exploration in the southern Caspian Sea, Estuar. Coast. Schelf S., 71, 170-180, 2007.

Peres-Neto, P. R., Legendre, P., Dray, S., and Borcard, D.: Variation partitioning of species data matrices: estimation and comparison of fractions, Ecology, 87, 2614-2625, 2006.

Poliński, V.: Limnološka ispitivanja Balkanskog Poluostrva I. Reliktna fauna gasteropoda Ohridskog Jezera, Glas Srpska Kraljevske Akademije, Belgrade, 137, 129-182, 1929.

Popovska, C. and Bonacci, O.: Basic data on the hydrology of Lakes Ohrid, Hydrol. Process., 21, 658-664, 2007.

Prendergast, J. R., Quinn, R. M., Lawton, J. H., Eversham, B. C., and Gibbons, D. W.: Rare species, the coincidence of diversity hotspots and conservation strategies, Nature, 365, 335-337, 1993.

R Development Core Team: R: A language and environment for statistical computing, R Foundation for Statistical Computing, Vienna, Austria, ISBN 3-900051-07-0, http://www.r-project.org, 2009.

Radoman, P.: Hydrobioidea a superfamily of Prosobranchia (Gastropoda), I Systematics, Serbian Acadamy of Sciences and Arts, Belgrade, 256 pp., 1983.

Radoman, P: Hydrobioidea a superfamily of Prosobranchia (Gastropoda), II Origin, Zoogeography, Evolution in the Balkans and Asia Minor, Monographs Institute of Zoology1, Beograd, 180 pp., 1985.

Reid, D. F. and Orlova, M. I.: Geological and evolutionary underpinnings for the success of Ponto-Caspian species invasions in the Baltic Sea and North American Great Lakes, Can. J. Aquat. Sci., 59, 1144-1158, 2002.

Rohde, R. A. and Muller, R.: Cycles in fossil diversity, Nature, 434, 208-210, 2005.

Scholz, C. A.: East African megadroughts between 135 and 75 thousand years ago and bearing on early-modern human origins, P. Natl. Acad. Sci. USA, 104, 16416-16421, doi:10.1073/pnas.070387410, 2007.

Schultheiß, R., Albrecht, C., Bößneck, U., and Wilke, T.: The ne- glected side of speciation in ancient lakes: phylogeography of an inconspicuous mollusk taxon in lakes Ohrid and Prespa, Hydrobiologia, 615, 141-156, 2008.

Schultheiß, R., Van Bocxlaer, B., Wilke, T., and Albrecht, C.: Old fossils-young species: evolutionary history of an old endemic gastropod assemblage in Lake Malawi, P. Roy. Soc. B-Biol. Sci., 276, 2837-2846, doi:10.1098/rsb.2009.0467, 2009.

Schultheiß, R., Wilke, T., Jørgensen, A., and Albrecht, C.: The birth of an endemic species flock: demographic history of the Bellamya group (Gastropoda, Viviparidae) in Lake Malawi, Biol. J. Linn. Soc., 102, 130-143, 2011.

Sell, J., Wysocka, A., Kostoski, G., and Trajanovski, S.: Genetic diversification of the endemic Ochridogammarus complex in Lake Ohrid explored with mtDNA sequencing, 1st Symposium for Protection of Natural Lakes in Republic of Macedonia, Ohrid, 72-73, 2007.

Smith, T. W. and Lundholm, J. T.: Variation partitioning as a tool to distinguish between nich and neutral processes, Ecography, 33 , 648-655, doi:10.1111/j.1600-0587.2009.06105.x, 2010.

Sitnikova, T. Y.: Endemic gastropod distribution in Baikal, Hydrobiologia, 568(S), 207-211, 2006.

Stanković, S.: The Balkan Lake Ohrid and its living world, Monographiae biologicae, Vol. IX., edited by: Junk, W., Bodenheimer F. S., and Weisbach, W. W., Den Haag, 358 pp., 1960.

Stone, L. and Roberts, A.: The checkerboard score and species distributions, Oecologia, 85, 74-79, 1990.

Strayer, D. L.: Challenges for freshwater invertebrate conservation, J. N. Am. Benthol. Soc., 25(2), 271-287, 2006.

Tocko, M. and Sapkarev, J.: Annual variations of the important zoobenthic populations in Lake Ohrid, Angew. Limnol., 20(2), 1090-1095, 1978.

Trajanovski, S., Albrecht, C., Schreiber, K., Schultheiß, R., Stadler, T., Benke, M., and Wilke, T.: Testing the spatial and temporal framework of speciation in an ancient lake species flock: the leech genus Dina (Hirudinea: Erpobdellidae) in Lake Ohrid, Biogeosciences, 7, 3387-3402, doi:10.5194/bg-7-3387-2010, 2010.

Ulrich, W.: Pairs - a FORTRAN program for studying pair-wise species associations in ecological matrices, www.uni.torun.pl/ $\sim$ ulrichw, last access: 2 November 2010, 2008.

UNEP: Convention on biological diversity, UNEP, Nairobi, Kenya, 1992.

Van Bocxlaer, B., Van Damme, D., and Feibel, C. S.: Gradual versus punctuated equilibrium evolution in the Turkana Basin molluscs: evolutionary events or biological invasions?, Evolution, 62(3), 511-520, 2008.

Vogel, H., Wessels, M., Albrecht, C., Stich, H.-B., and Wagner, B.: Spatial variability of recent sedimentation in Lake Ohrid (Albania/Macedonia), Biogeosciences, 7, 3333-3342, doi:10.5194/bg7-3333-2010, 2010.

Watzin, M. C., Puka, V., and Naumoski, T. B.: Lake Ohrid and its watershed, state of the environment report, Lake Ohrid Conservation Project, Tirana, Albania and Ohrid, Macedonia, edited by: Guseska, D., Hydrobiological Institute Ohrid, 134 pp., 2002.

Weir, J. T.: Divergent timing and patterns of species accumulation in lowland and highland neotropical birds, Evolution, 60(4), 842-855, 2006.

Whittaker, R. J.: Evolution and measurement of species diversity, Taxon, 21(2/3), 213-251, 1972.

Wilke, T. and Albrecht, C.: How to stop the creeping biodiversity 
crisis in Lake Ohrid? Suggestions for sustainable conservation strategies of biodiversity hotspots, in: Proceedings of the I Symposium for protection of the natural lakes in Republic of Macedonia, Ohrid, Republic of Macedonia, 31 May-3 June 2007, 44-45, 2007.

Wilke, T., Schultheiß, R., and Albrecht, C.: As time goes by: a simple fool's guide to molecular clock approaches in invertebrates, Am. Malacol. Bull., 27, 25-45, 2009.

Wilke, T., Schultheiß, R., Albrecht, C., Bornmann, N., Trajanovski, S., and Kevrekidis, T.: Native Dreissena freshwater mussels in the Balkans: in and out of ancient lakes, Biogeosciences, 7, 3051-3065, doi:10.5194/bg-7-3051-2010, 2010.

Williams, P., Gibbons, D., Margules, C., Rebelo, A., Humphries, C., and Pressey, R.: A comparison of richness hotspots, rarity hotspots and complementary areas for conserving diversity using British birds, Conserv. Biol., 10, 155-174, 1996.
Williamson, P. G.: Palaeontological documentation of speciation in Cenozoic molluscs from the Turkana Basin, Nature, 293, 437443, 1981.

Wilson, A. B., Glaubrecht, M., and Meyer, A.: Ancient lakes as evolutionary reservoirs: Evidence from the thalassoid gastropods of Lake Tanganyika, P. Roy. Soc. Lond. B Bio., 271, 529-536, doi:10.1098/rspb.2003.2624, 2004.

Wysocka, A., Kostoski, G., Kilikowska, A., Wróbel, B., and Sell, J.: The Proasellus (Crustacea, Isopoda) species group, endemic to the Balkan Lake Ohrid: a case of ecological diversification?, Fund. Appl. Limnol., 172(4), 301-313, 2008. 